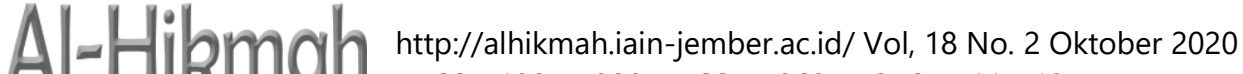 P-ISSN:1907-4328, E-ISSN : 2685-4376/P. 117-134
}

\section{Islam, Peradaban Masa Depan}

\author{
Abdul Wadud Nafis \\ Institut Agama Islam Negeri Jember \\ nafiswadud@yahoo.com
}

\begin{abstract}
Islam is a universal civilization, a religion of equity not destruction. Islam encourages its followers to believe in their own abilities and not depend on what other people give while prioritizing what is beneficial for them. Islamic civilization will develop if it is able to communicate with the local culture in a selective manner and still adheres to Aswaja (Ahlus sunnah Wal Jamaah) values. If Islam blindly followed the developing culture in the society, both the local and foreign cultures, Islam would lose its identity and the Muslim community would be separated from its cultural roots. The values of Islamic civilization are: Rabbiyah value (the divine values), Insâniyah value (the human value). Wâqi'iyah value (the practical value), Wasathiyah value (the Islamic moderatation value), Tawâzun value (the equilibration value), Tsabât value (the fixity value) and Murûnah value (the flexibility value). The nobleness of Islamic values should not only be a theory, but also needs to be implemented. The deeper the implementation, the more sublime the civilization will be. Human life must be based on the belief that we belong to Allah and to Him we shall return.
\end{abstract}

Keywords: Civilization, Universal

\section{Abstrak}

Islam adalah peradaban universal, agama kesetaraan bukan kehancuran. Islam mendorong umatnya untuk percaya pada kemampuan mereka sendiri dan tidak bergantung pada apa yang diberikan orang lain dengan tetap mengutamakan apa yang bermanfaat bagi mereka. Peradaban Islam akan berkembang jika mampu berkomunikasi dengan budaya lokal secara selektif dan tetap berpegang pada nilainilai Aswaja (Ahlus sunnah Wal Jamaah). Jika Islam membabi buta mengikuti budaya yang berkembang di masyarakat, baik budaya lokal maupun asing, Islam akan kehilangan jati dirinya dan umat Islam akan lepas dari akar budayanya. Nilainilai peradaban Islam adalah: nilai Rabbiyah (nilai ketuhanan), nilai Insâniyah (nilai kemanusiaan). Nilai Wâqii'iyah (nilai praktis), nilai Wasathiyah (nilai moderasi Islam), nilai Tawâzun (nilai keseimbangan), nilai Tsabât (nilai ketetapan) dan nilai Murûnah (nilai fleksibilitas). Keluhuran nilai-nilai Islam seharusnya tidak hanya menjadi teori, tetapi juga perlu diimplementasikan. Semakin dalam implementasinya, semakin luhur peradabannya. Kehidupan manusia harus dilandasi dengan keyakinan bahwa kita adalah milik Allah dan kepada-Nya kita akan kembali.

Kata kunci: Peradaban, Universal 


\section{Pendahuluan}

Perbincangan mengenai peradaban dianggap menarik kiranya bukan karena fungsinya dalam membantu melakukan rekonstruksi terhadap kejayaan masa lalu umat manusia. Perbincangan mengenai peradaban menarik dan diperlukan untuk melakukan proyeksi terhadap masa depan umat manusia. Dengan demikian, peradaban tidak lagi dipandang sebagai fenomena etnis dan antropologis, melainkan sebagai bagian dari gejala politik dan ekonomi dunia, bankan sisi kehidupan lainnya. ${ }^{1}$

Di sisi lain, Islam memang berbeda dari agama-agama lain. H.A.R. Gibb di dalam bukunya Wither Islam menyatakan: Islam is indeed much more than a system of theology, it is a complete civilization. Artinya: Islam sesungguhnya lebih dari sekedar agama, ia adalah suatu peradaban yang sempurna. Karena itulah Penulis tertarik untuk membahas Islam dan peradaban.

\section{Persamaan dan Perbedaan Antara Kebudayaan dan Peradaban}

Kebudayaan dalam bahasa arab al-Tsaqâfah dan dalam bahasa Inggris adalah culture. Kata kebudayaan berasal dari bahasa sansekerta "Buddhayah" yang merupakan bentuk jamak dari kata "Buddhi" yang berarti budi atau akal. Akal atau budi itu mempunyai unsur cipta, rasa dan karsa. Hasil dari ketiga unsur budi itulah yang disebut kebudayaan. ${ }^{2}$

Peradaban dalam bahasa arab adalah hadhârah dan dalam bahasa Inggris adalah civilization. Peradaban merupakan suatu kebudayaan yang lebih halus, tinggi dan indah. Seperti kesenian, ilmu pengetahuan atau untuk menunjukkan suatu kebudayaan yang lebih maju dan kompleks seperti sistem tekhnologi, sistem kenegaraan dan lain-lain. ${ }^{3}$

Menurut Effat al Sharqawi kebudayaan adalah bentuk ungkapan tentang semangat mendalam suatu masyarakat. Sedangkan manifestasi-manifestasi kemajuan mekanis dan teknologi lebih berkaitan dengan peradaban. Kalau kebudayaan lebih banyak direfleksikan dalam seni, sastra, religi (agama) dan moral, maka peradaban terefleksi dalam politik, ekonomi dan tekhnologi. ${ }^{4}$

Sebuah peradaban adalah bentuk budaya yang paling tinggi dari suatu kelompok masyarakat dan tataran yag paling luas dari identitas budaya kelompok masyarakat manusia yang dibedakan secara nyata dari makhluk-makhluk lainnya. Ia terdefinisikan baik dalam faktor-faktor objektif pada umumnya seperti bahasa, sejarah, agama, kebiasaan-kebiaasaan, institusi-institusi maupun identifikasi diri

\footnotetext{
${ }^{1}$ Nasir Tamara, Elza Peldi Taher, Agama dan Dialog Antar Peradaban, (Jakarta: Paramadina, 1996), XVI.

${ }^{2}$ Machmoed effendhie, Sejarah Budaya, (Jakarta: Rajawali, 1999), 2.

${ }^{3}$ Ibid, 3 .

${ }^{4}$ Effat al Sharqawi, Filsafat Kehidupan Islam, (Bandung: Pustaka, 1986), 53.
} 
yang bersifat subjektif. ${ }^{5}$

\section{Faktor-Faktor yang Mempengaruhi Perkembangan Peradaban}

Peradaban dimiliki bersama oleh suatu kelompok masyarakat. Untuk lebih mudahnya, dapat dikatakan bahwa masyarakat adalah wadahnya, sedangkan peradaban adalah isi wadah yang berupa masyarakat. Faktor-faktor yang membedakan perkembangan peradaban antara satu masyarakat dan yang lain adalah:

1. Faktor Alam (lingkungan geografis), meliputi tata letak bumi dan iklimnya. Faktor ini mempunyai pengaruh yang besar terhadap pembentukan peradaban.

2. Faktor Kebiasaan. Apabila diperhatikan kebiasaan-kebiasaan masyarakat di dunia, akan dijumpai perilaku-perilaku yang di satu masyarakat dilarang, sedangkan di lain masyarakat tidak dilarang atau tidak dipersoalkan. Hal ini dapat mempengaruhi perkembangan peradaban di masyarakat yang bersangkutan.

3. Faktor Pelapisan Sosial

Lapisan sosial terbentuk karena setiap masyarakat mempunyai sikap menghargai hal-hal tertentu dalam bidang-bidang kehidupan sehingga menghasilkan peradaban yang berbeda.

4. Faktor Ideologi

Ideologi merupakan kumpulan gagasan, dasar serta tatanan yang baik dalam kehidupan bermasyarakat dan bernegara. Ideologi digunakan sebagai pedoman hidup dan pandangan hidup bangsKepercayaan / Religi

Peradaban yang didasarkan pada suatu agama mungkin berbeda dengan peradaban yang didasarkan pada agama yang lain karena perbedaan sistem nilai yang dianut.

5. Faktor Ilmu Pengetahuan dan Teknologi

Manusia terus berusaha mempelajari ilmu pengetahuan dan teknologi untuk mengetahui ilmu dan mendalami segi kehidupan dan mengembangkan peradaban. ${ }^{6}$

\section{Sikap Islam Terhadap Peradaban}

Islam adalah peradaban yang universal, agama keadilan bukan menghancurkan. Islam tidak senang menunggu apa yang diberikan orang lain, tapi menuntut untuk percaya pada kemampuan sendiri, mendahulukan yang bermanfaat, merealisasikan hal-hal yang baik yang dibutuhkan oleh orang banyak, Sabda Nabi :

${ }^{5}$ Samuel P. Hungtington, The Clash Of Cilivization and The Remaking Of World Order, terj. M Sadat Ismail (Yogyakarta: Qalam, 2003), 43.

${ }^{6}$ Posman Simanjuntak, Antropologi, (Jakarta: Erlangga, 1997), 46. 


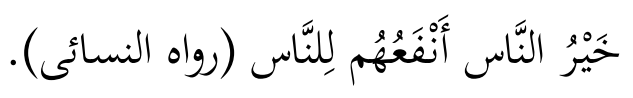

Sebaik-baik manusia adalah yang paling bermanfaat bagi orang lain.

Islam sangat memperhatikan ilmu dan amal, kerja keras dan melaksanakan tugas dengan baik, keadilan dan persamaan, kasih sayang dan kebaikan, pengorbanan dan perdamaian. Semua itu merupakan tujuan tertinggi dari sebuah peradaban. $^{7}$

Menurut hemat penulis, Islam sangat memperhatikan peradaban karena menciptakan peradaban Islami itu merupakan bagian dari tujuan pokok hidup manusia sebagaimana yang telah dijelaskan dalam al Qur'an. Imam ar Raghib al Isfahani dalam bukunya "al Dzarîah ila Makârimi al Syarî'ah” menjelaskan tujuan-tujuan pokok hidp manusia sebagai berikut:

1. Beribadah kepada Allah. Yaitu taat mutlaq kepadaNya Sebagai Firman-Nya:

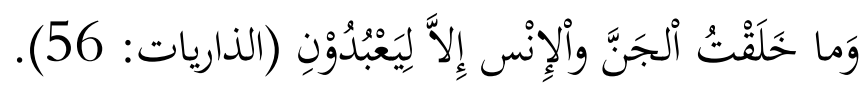

“Tidaklah Aku ciptakan Jin dan Manusia melainkan agar meraka menyembahKu. ” (adz-Dzariyat; 56) ${ }^{8}$

2. Menjadi Kholifah dimuka bumi yaitu menegakkan kebenaran dan keadilan serta berprilaku dengan akhlaq Allah SWT dengan kapasitas manusiawi.

Sebagaimana Firman Allah:

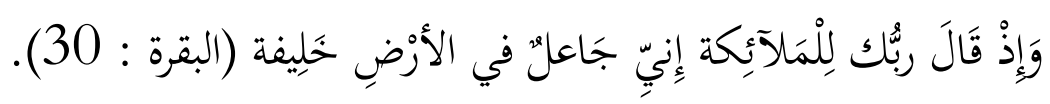

"Ingatlah ketika Tuhanmu berfirman kepada Malaikat: "Sesungguhnya Aku hendak menjadikan seorang khalifah di muka bumi." (al-Baqarah; 30). ${ }^{9}$

3. Memakmurkan bumi dengan membangun peradaban yang didasarkan pada sistem nilai sebagaimana yang akan di bahas selanjutnya. ${ }^{10}$

Allah berfirman :

$$
\text { هوأنشأكم من الأرض واستعمركم فيها (هود : 61). }
$$

Dia telah menciptakan kamu dari bumi (tanah) dan menjadikan kamu pemakmurnya (hud; 61). ${ }^{11}$

${ }^{7}$ Wahbah Az Zuhaily, al Qur'ân al Karim Bainah al Tasyri'iyyatu wa Khasâishuhu al Hadhâriyah, (Beirut: Darul Fikr al Muashir, 1993), 84.

${ }^{8}$ al-Qur'an, $51: 56$

${ }^{9}$ al-Qur'an, $2: 30$

${ }^{10}$ Yusuf al Qardhawiy, Al Islâm Hadârah al Ghâd, Terj. Mustolah Maufur ( Jakarta : Pustaka Al Kautsar ). 172

${ }^{11}$ al-Qur'an, $11: 61$

120 | Abdul Wadud Nafis 


\section{Pembagian Peradaban}

Islam membagi budaya menjadi tiga macam :

Pertama : Kebudayaan yang tidak bertentangan dengan Islam. Dalam kaidah fiqh disebutkan : " al adatu muhakkamatun " artinya bahwa adat istiadat dan kebiasaan suatu masyarakat, yang merupakan bagian dari budaya manusia, mempunyai pengaruh di dalam penentuan hukum. Tetapi yang perlu dicatat, ataupun arsitektur Jawa yang berbentuk Joglo.

Untuk hal-hal yang sudah ditetapkan ketentuan dan kreterianya di dalam Islam, maka adat istiadat dan kebiasaan suatu masyarakat tidak boleh dijadikan standar hukum. Sebagai contoh adalah apa yang di tulis oleh Ahmad Baaso dalam sebuah harian yang menyatakan bahwa menikah antar agama adalah dibolehkan dalam Islam dengan dalil " al adatu muhakkamatun " karena nikah antar agama sudah menjadi budaya suatu masyarakat, maka dibolehkan dengan dasar kaidah di atas. Pernyataan seperti itu tidak benar, karena Islam telah menetapkan bahwa seorang wanita muslimah tidak diperkenankan menikah dengan seorang kafir.

Kedua : Kebudayaan yang sebagian unsurnya bertentangan dengan Islam , kemudian di " rekonstruksi" sehingga menjadi Islami.Contoh yang paling jelas, adalah tradisi Jahiliyah yang melakukan ibadah haji dengan cara-cara yang bertentangan dengan ajaran Islam , seperti lafadh " talbiyah " yang sarat dengan kesyirikan, thowaf di Ka'bah dengan telanjang. Islam datang untuk meronstruksi budaya tersebut, menjadi bentuk "Ibadah" yang telah ditetapkan aturan-aturannya. Contoh lain adalah kebudayaan Arab untuk melantukan syair-syair Jahiliyah. Oleh Islam kebudayaan tersebut tetap dipertahankan, tetapi direkonstruksi isinya agar sesuai dengan nilai-nilai Islam.

Ketiga: Kebudayaan yang bertentangan dengan Islam. Seperti, budaya “ ngaben " yang dilakukan oleh masyarakat Bali. Yaitu upacara pembakaran mayat yang diselenggarakan dalam suasana yang meriah dan gegap gempita, dan secara besar-besaran. Ini dilakukan sebagai bentuk penyempurnaan bagi orang yang meninggal supaya kembali kepada penciptanya. Upacara semacam ini membutuhkan biaya yang sangat besar. Hal yang sama juga dilakukan oleh masyarakat Kalimantan Tengah dengan budaya "tiwah", sebuah upacara pembakaran mayat. Bedanya, dalam " tiwah" ini dilakukan pemakaman jenazah yang berbentuk perahu lesung lebih dahulu. Kemudian kalau sudah tiba masanya, jenazah tersebut akan digali lagi untuk dibakar. Upacara ini berlangsung sampai seminggu atau lebih. Pihak penyelenggara harus menyediakan makanan dan minuman dalam jumlah yang besar, karena disaksikan oleh para penduduk dari desa-desa dalam daerah yang luas. Di daerah Toraja, untuk memakamkan orang yan meninggal, juga memerlukan biaya yang besar. Biaya tersebut digunakan untuk untuk mengadakan hewan kurban yang berupa kerbau. Lain lagi yang dilakukan oleh masyarakat Cilacap, Jawa tengah. Mereka mempunyai budaya " Tumpeng 
Rosulan “, yaitu berupa makanan yang dipersembahkan kepada Rosul Allah dan tumpeng lain yang dipersembahkan kepada Nyai Roro Kidul yang menurut masyarakat setempat merupakan penguasa Lautan selatan ( Samudra Hindia ).

\section{Islam dan Sistem Nilai}

$$
\text { صِبْغَة الله وَمَن اَحْسَنَ مِن الله صِبْغَة وَنَخْن لَه عَابِدُونَ. (البقرة : 138) }
$$

Itulah celupan (agama) Allah siapakah yang lebih baik celupannya dari Allah? dan kami hanya menyembah kepada-Nya. (al Baqarah : 138) ${ }^{12}$

Islam memiliki ciri-ciri khas yang istimewa dalam sistem dan tata nilainya. Ciri khas itu antara lain :

1. Nilai Rabbiyah (nilai ketuhanan). Sistem dan tata nilai Islam itu didasarkan pada petunjuk Allah sebagaimana yang ada dalam al Qur'an dan Hadits yang dibawakan oleh Rasul Allah. Tata nilai itu dijiwai oleh kesadaran bahwa hidup ini berasal dari Allah dan menuju pada Allah (إنِّللَه و إِنَّا إلِيه رَاجِعُونَ)

2. Nilai Insâniyah (nilai kemanusian). Tata nilai Islam didasarkan pada kemampuan manusia. Firman Allah :

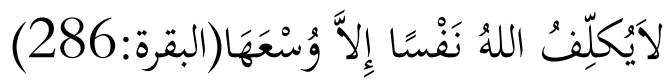

Allah tidak memberati manusia, melainkan sekedar tenaganya. (al Baqarah : $286)^{13}$

Tata nilai itu dimaksudkan untuk ketentuan dan kebahagiaan manusia di dunia dan di akhirat.

3. Nilai Wâqi'iyah (nilai realistis). Tata nilai Islam itu realistis dalam aqidah, ibadah, akhlaq, pendidikan, tahlil dan tahrim dan dalam bidang-bidang lainnya hal ini memudahkan manusia untuk melaksanakannya.

4. Nilai Syamûliyah (nilai universal). Ajaran Islam mencakup semua aspek kehidupan manusia baik dalam kehidupan pribadi, maupun kehidupan berbangsa bernegara.

5. Nilai Wasathiyah (nilai moderat). Ajaran Islam berada di antara ajaran-ajaran agama lain yang berat dan yang ringan. Ia juga moderat dalam kepercayaan terhadap yang ghaib dan maddah (ghaib dan nyata) serta dalam memperlakukan Nabi (tidak mensejajarkan Nabi dengan Tuhan, atau Nabi dengan manusia biasa). ${ }^{14}$

6. Nilai Tawâzun (nilai keseimbangan). Nilai ini menjaga Islam dari

12 al Qur'an, $2: 138$

${ }^{13}$ al Qur'an, $2: 286$

${ }^{14}$ Yusuf Al Qardhawi, Al Khasâisul 'Âmmah Li al Islâm, (Beirut : Muassasah Al Risâlah, 1983). 
kecenderungan berat sebelah dari ketimpangan yang berlebih-lebihan dan dari kemungkinan terjadinya benturan-benturan.

7. Nilai Tsabât (tetap tak berubah) dan Nilai Murûnah (fleksibel)

Ajaran agama bergerak dalam lingkungan yang tetap dan di sekitar poros yang tetap. Landasan ajaran Islam dan nilai-nilai yang terkandung di dalamnya itu tidak berubah dan tidak berkembang di saat berubahnya gejala-gejala kehidupan nyata dan di saat berubahnya bentuk-bentuk kondisi praktis. ${ }^{15}$

Ajaran Islam itu tidak berubah dalam tujuan, tapi fleksibel dalam sarana dan metode dalam masalah ushul dan kulliyat tapi fleksibel dalam masalah furû' dan juzziyat tetap dalam nilai-nilai agama dan akhlaq, fleksibel dalam urusan dunia dan ilmu. ${ }^{16}$

\section{Peradaban Sebagai Implimentasi}

\section{Islam dan Keadilan}

Konsep tauhîd dan khilâfah mengandung pengertian persatuan dan persaudaraan fundamental umat manusia. Islam tidak memperbolehkan diskriminasi berdasarkan ras, jenis kelamin, agama, bahasa dan etnis. Maka ahli sosiologi antropologi mengatakan bahwa Islam merupakan religion of justice (agama keadilan). Maka setiap orang Islam bisa menjadi trouble maker bagi kemapanan yang tidak adil. ${ }^{17}$

Islam adalah keimanan universal yang sederhana, mudah dimengerti dan dinalar. Ia didasarkan pada 3 prinsip fundamental yaitu tauhîd (keesaan), khilâfah (perwakilan) dan 'adâlah (keadilan). Prinsip-prinsip ini membentuk pandangan dunia Islam, maqâshid dan strategi. ${ }^{18}$

Keadilan dalam Islam adalah memberikan hak pada yang berhak tanpa membeda-bedakan mereka dan tanpa memandang nasab, harta, kekuatan, kelemahan, permusuhan dan perwaliannya. ${ }^{19}$ Nilai keadilan dalam masyarakat dapat dilihat dengan kewajiban berzakat yang mengandung banyak hikmah dan manfaat yang sangat besar dan mulia bagi Muzakkî, Mustahiq dan masyarakat secara keseluruhan). ${ }^{20}$

Nilai keadilan yang termanifestasi dalam bentuk pemerataan pendapat yang dilakukan oleh negara dapat berbentuk Baitul Mâl, yang menurut sejarah keuangan

${ }^{15}$ Sayyid Quthb, Al Mutashawwaru al Islâmi wa Muqawwamâtuhu, terjemah.

${ }^{16}$ Yusuf Qardhawy, Al Islâm wa al Ilmaniyah Wajhan li Wajhin (Beirut: Muassasah Ar Risalah, 1992), 151.

${ }^{17}$ Amin Rais, Tauhid Sosial (Bandung : Mizan, 1988), 110.

${ }_{18}$ Umer Chapra, Islam and The Economic Challege, terj. Ikhwan Abidin Basri (Jakarta : Gema Insani Press, 2000), 204.

19 Rasyad Hasan Khalil, Mafhum al Musâwah fî al Islâm dirâsah Muqâranah (Riyâdh : Dâr al Rasyîd li al Nasyr wa al Tauzî', tt), 30.

20 Nur Jihad, "Implementasi Undang-undang nomor 38 th. 1999 tentang Pengelolaan Zakat," Hukum, 17 (Agustus, 2001), 67. 
negara dalam Islam terdiri atas zakat mal, rampasan perang atau (Ghanîmah), fai', pajak harta temuan atau karun (Rikâz), iuran kaum dzimmy (jizyah), bea cukai ('usr), pajak tanah (kharâj), harta warisan yang tidak ada ahli ahli warisnya dan barang-barang yang tidak bertuan. Dari jalur perorangan, terdiri dari zakat fitrah, kifârat-kifârat, wasiat, nadzar, wakaf dan infâq. ${ }^{21}$

\section{Islam dan Hak-hak Asasi Manusia}

Hak-hak asasi manusia adalah hak-hak individual yang berkembang dari pemikiran modern Eropa tentang hukum alam. Hak-hak ini terus berkembang di Barat menjadi standar institusional - legal. Dengan Deklarasi Universal Hak-hak Asasi Manusia (UDHR) Perserikatan Bangsa Bangsa (PBB), hak-hak ini sekarang telah menjadi hukum internasional. ${ }^{22}$

Dalam membahas HAM, perlu kita perhatikan uraian dalam kitab-kitab ushûl al-fiqh mengenai dharûriyyat al-khams (lima prinsip dasar) dalam agama yang harus selalu dijaga atau dipelihara. Yaitu, (a) memelihara agama (hifzh al-dîn), (b) memelihara jiwa (hifzh al-nafs), (c) memelihara keturunan (hifzh al-nasb), (d) memelihara harta (hifzh al-mâl), dan (e) memelihara akal (hifzh al-aql). ${ }^{23}$ Kelima prinsip dasar itu juga dianggap sebagai nilai-nilai universal yang ditemui di semua agama. Dengan kelima hal inilah, kemaslahatan kehidupan umat akan terjaga. Jika kelima hal ini dapat terwujud, berarti HAM juga akan terwujud.

Kelima prinsip dasar itu hendaknya harus dipahami bukan hanya secara pasif dan protective yang defensive, yakni pemeliharaan dari serangan luar. Namun juga harus secara aktif atau bahkan progesif, yakni untuk memperoleh yang maksimal dari praktek kelima prinsip dasar tersebut. Ambil contoh prinsip "memelihara akal". Pemahaman pasif selalu diberi pengertian bahwa akal harus dipelihara, jangan sampai berbuat merusak akal seperti menyalahgunakan narkoba. Demi memelihara akal, maka narkoba diharamkan. Pemahaman aktif, bukan sekedar memelihara akal dari serangan narkoba, namun bagaimana memanfaatkan akal semaksimal mungkin agar dapat digunakan, diperankan dan difungsikan secara maksimal, tanpa harus mengganggu akal orang lain. Dari sinilah akan dihasilkan kebebasan berpikir dan berpendapat. Dan dari sini pula dapat dihasilkan akal yang kritis, kreatif, inovatif dan produktif untuk kemajuan di dunia dan keselamatan di akhirat. ${ }^{24}$

Abdurrahman wahid telah membuktikan bahwa beberapa prinsip dasar dalam Islam yang sesuai dengan deklarasi universal hak asasi manusia adalah sebagai berikut :

\section{Ibid, 68.}

22 Abdullâh Ahmed an Na'îm, Mohammed Arkoun, dkk, Islamic Law Reform and Human Rights Challenges and Rejoinders, terj. Farid Wayidi (Yogyakarta : LKIS, 1996), 85.

${ }^{23}$ Wahbah Az Zuhaily, Ushûl al Fiqh al Islâmy (Beirut : Darul Fikr, 1986), 1021.

24 Qodri Azizy, Melawan Globalisasi Reinterpretasi Ajaran Islam (Yogyakarta : Pustaka Pelajar, 2003), 167. 

a. Perlindungan dari penindasan fisik di luar batas hukum
b. Kebasan beragama, termasuk peniadaan paksaan dalam beragama
c. Perlindungan keluarga dan keturunan
d. Perlindungan hak milik pribadi, dan
e. Perlindungan profesi seseorang 25

\section{Islam dan Politik}

\section{a. Politik Perdamaian}

Dalam sejarah kehidupan Nabi Muhammad saw. Serta para sahabat ketika menyiarkan islam keluar jazirah yakni imperium - imperium Romawi dan Persia dimana terdapat umat islam di kawasan tersebut selalu dikemukakan tiga syarat yakni : masuk Islam, membeyar upeti, perang. Alternatif terakhir adalah perang, Jika tidak sanggup maka harus bersedia masuk islam atau bayar upeti. Kenapa Nabi Muhammad saw. para sahabat menyuruh masuk Islam yang sesungguhnya sangat kecil resikonya, bahkan tidak apapun yang akan terjadi. Yang terjadi hanyalah proses keislaman dan itupun tidak beloh di paksakan, hanya saja kawasan kawasan tersebut secara tidak langsung masuk wilayah umat islam, karena punya kepentingan dengan umat yang berada di wilayah tersebut. Sehingga dengan pilihan syarat pertama tersebut tidak setitik darah pun yang tertumpah.

Tetapi jika syarat pertama tidak dipenuhi, maka boleh membayar upeti tiap kepala, sedangkan anak - anak dan orang jompo bebas dari upeti yang ditetapkan menurut peraturan. Di sini islam tetap menginginkan jalan damai yang baik. Dan satu wilayah yang ingin membayar upeti, maka wilayah tersebut keamanannya adalah tanggung jawab pemerintahan islam. Dua alternatif ini memberikan pengertian kepada kita bahwa betapa besar keinginan umat islam itu menghindarkan diri dari kontak senjata, dan itu berarti politik islam sangat menginginkan perdamaian secara baik-baik. Alternatif yang paling terakhir yakni perang tidak dilakukan secara tiba - tiba tetapi juga diberi tenggang waktu untuk berfikur sejenak siapa tau mau masuk islam atau membayar upeti. Kemudian bila tidak ada harapan lagi maka perang terbukapun diumumkan sehingga kedua belak pihak saling mempersiapkan persenjataan atau perbekalan selama perang yang akan menentukan siapa yang menang dan siapa yang kalah.

Peperangan di masa Rosulullah saw. dan para sahabat mengajarkan agar tidak membunuh anak - anak, orang tua jompo, wanita, pohon tidak boleh di tebang, kebun tidak boleh dirusak, sumur tidak boleh di tutup, binatang tidak boleh di bunuh, rumah - rumah ibadah tidak boleh di rusak. Dan hentikan pertempuran jika musuh menyatakan menyerah.

Jika perilaku Rosulullah saw. Dan para sahabatnya itu di kaji lebih dalam,

25 Mohammed Hikam, Islâm, Demokratisasi dan Pemberdayaan Civil Society (Jakarta : Erlangga, 2000), 29. 
maka sesungguhnya perang sebagai alternatif ketiga bukanlah tujuan sama sekali, melainkan sekedar pelajaran pertama untuk orang - orang yang hatinya keras dan tidak mau menerima kebaikan secara bersama. Allah SWT. menyuruh umat berperang dengan alasan yang kuat demi perdamaian. ${ }^{26}$

\section{b. Politik Keadilan}

Sejarah islam adalah sejarah pertentangan abadi antara das sollen yakni kepemimpinan politik yang adil dan das sein yakni pelaksanaan kepemimpinan yang adil ini. Para sahabat telah memberikan contoh tentang pola penegakan kepemimpinan yang adil ini, sebagai berikut :

Pertama, tak melakukan tindakan penentangan dalam bentuk apapun, tetapi tetap menunjukakan apa yang kita yakini kebenarannya. Pola ini ditunjukan dalam perilaku ' Ali bin Abi Tholib k.w. Syarat utama pola ini ialah adanya kepemimpinan politik yang secara keseluruhan relatif adil, walaupun terdapat beberapa penyimpangan dari perinsip keadilan. Syarat kedua ialah pertimbangan kemaslahatan dan persatuan kaum muslim yang sangat diperlukan, karena umat dalam keadaan terancam

Kedua, perlawanan pasif seperti yang dilakukan ' Abdullah bin Mas'ud. Menurut pola ini, kita melepaskan keterikatan kita dengan sistem yang ada. Kita “ mengundurkan diri “. Kita memutuskan untuk tidak bekerja sama dengan sistem yang terbukti tidak adil.

Ketiga, penyadaran umat melalui kampanye penegakan keadilan seperti yang dilakukan 'Abu Dzar. Kita menyampaikan keritik terhadap sistem secara terbuka. Pola ketiga ini hanya berhasil dalam suatu sistem sosial yang menjamin kebebasan menyampaikan pendapat.

Keempat, pernyataan sikap bersama dalam bentuk petisi seperti yang dilakukan oleh 'Ammar bin Yasir dan kawan - kawan. Petisi ini akan memiliki kekuatan politis apabila para penandatangannya merupakan tokoh - tokoh umat yang berpengaruh.

Kelima, bekerja sama dengan sistem yang dzalim ( al-dukhul fi a'mal salathin al-jawr ), tetapi dengan syrat - syarat tertentu : misalnya, menggunakan setiap peluang untuk paling tidak mencegah terjadinya kedzaliman. Kita melihat pola ini pada perjuangan beberapa imam mazhab seperti Ja'far Al-Shadiq, Abu Hanifah, dan Malik. ${ }^{27}$

Politik keadilan ini juga dapat di lihat dalam kisah Qadhi Syuraih yang menangani kasusnya Ali Bin Abi Tholib yang sedang menjabat khalifah dan kehilanmgan sebuah baju perang. Ternyata baju perang itu ada ditangan seoarang

${ }^{26}$ A.M. Saifuddin, Ada Hari Esok, (Jakarta : Amanah Putera Nusantara, 1995), 198 dan 199.

${ }^{27}$ Jalaluddin Rahmat “ Kepemimpinan Politik dan Cita Keadilan : Persepektif Sejarah Islam, “Al Hikmah, 8 ( Januari-Maret, 1993), 61-62. 
Nasroni. Setelah kasus ini di ajukan ke pengadilan, ternyata Qadhi Syuraikh memenangkan orang Nasrani, karena Ali tidak punya saksi yang membuktikan bahwa baju perang itu miliknya. Beberapa saat setelah persidangan selesai, orang nasrani tersebut kembali dan berkata: " saya bersaksi bahwa ini hukum yang di bawa para Nabi. Ini baju perang Ali yang jatuh ketika mau berangkat ke Siffin. Karena itu saya akan masuk islam " kemanusian dia membaca syahadat. ${ }^{28}$

\section{Islam dan Demokrasi}

Karakteristik utama dari sistem yang demokratis adalah

a. Kebebasan berbicara ( freedom of speech).

b. Sistem pemilihan yang bebas (free elections).

c. Pengakuan terhadap pemerintahan mayoritas (Majority rule) dan hak-hak minoritas ( minority rights )

d. Partai - partai politik dalam sistem yang demokratis memainkan peranan penting

e. Pemisahan antara legislatif, eksekutif, dan yudikatif

f. Otoritas konstitusional ( Constitusional Authority )

g. Kebebasan berbuat (freedom of action) ${ }^{29}$

Bersandar pada dasar agama di atas kalangan ulama' islam telah melakukan elaborasi terhadap konsep-konsep barat untuk mendasari argumen-argumen mereka tentang model - model pemerintahan yang demokratis, masyarakat yang mejemuk dan jaminan atas HAM. Konsep-konsep tersebut selanjutnya di elaborasikan oleh pemikir muslim klasik da abad pertengahan kedalam istilah-istilah politik islam seperti shura (musyawarah), ijma' (konsensus) dan ahl al-dhimma (hak minoritas). Konsep-konsep islam klasik dan abad pertengahan ini kemudian di aktualisasikan kembali oleh para pemikir muslim modern dengan istilah demokrasi yang merupakan diskursus tentang doktri shura yang bersandar pada kebebasan memilih (ikhtiyâr) manusia, kontrak antara penguasa dan rakyat melalui janji kesetiaan (bay'at), dan konsesus masyarakat (ijmâ'). Konsep-konsep dasar demokrasi islam inilah, menurut Mousalli, merupakan metode-metode teoritis yang harus di jalankan dalam praksis politik islam. ${ }^{30}$

Sebagian orang mengklaim bahwa bangsa arab tidak siap melaksanakan pemerintahan yang didasarkan pada demokrasi atau syura dan bahwa meraka tidak menghargai perinsip dan niali - nilai demokrasi yang diperlukan untuk melaksanakan aturan hukum, sebagai lawan dari aturan-aturan individual. Klaim

${ }^{28}$ Yusuf al Qardhawy, Al Imân wa Al Hayâh, (Beirut: Al Risalah, 1998), 201.

${ }^{29}$ Charles Kurzman, Liberal Islam : A. Source book, terj. Bahrul Ulum, Heri Junaidi, ( Jakarta: Paramadina, 2003), 126.

${ }^{30}$ Komaruddin Hidayat, Azyumardi Azra, Demokrasi, Hak asasi manusia dan masyarakat madani (Jakarta: ICCE UIN Syarif Hidayatullah, 2006), 158. 
seperti itu merupakan penilaian yang buruk dan tidak adil. Setiap negara atau bangsa yang lahir dari peradaban islam diperintah supaya melaksanakan syura. Bangsa - bangsa tersebut di ajari perinsip-perinsip keadilan, persamaan, dan martabat kemanusiaan, nilai-nilai yang menopang dan memperkuat pengalaman kemanusiaan. Bangsa - bangsa tersebut sebenarnya juga memenuhi syarat untuk dapat melaksanakan demokrasi jika dibandingkan dengan bangsa - bangsa lainnnya. ${ }^{31}$

\section{Analisa}

Dalam pandangan penulis, peradaban dan kebudayaan sama - sama mencakup nilai - nilai, norma - norma, institusi - institusi dan pola - pola pikir yang menjadi bagianterpenting dari suatu masyarakat dan terwariskan dari generasi ke generasi. Pedaban dan kebudayaan sama-sama menunjuk pada seluruh pandangan hiduo manusia, tapi suatu peradaban adalah bentuk yang lebih luas.

Keluhuran nilai - nilai ajarab islam bukan hanya sebagai wacana, tapi perlu di implementasikan. Semakin dalam nilai - nilai itu diimplementasikan, maka semakin luhur peradaban yang dimunculkan.

Hidup manusia harus didasarkan pada suatu kesadaran bahwa إنا لله و إنا اليه راجعون. maksudnya kita hidup berasal dari Allah dan akan kembali padaNya. Hal ini dapat diilustrasikan sebagai berikut :

$$
\text { و إنا اليه راجعون ب Hidup } \longrightarrow
$$

Pemikiran ini dapat dikembangkan bahwa, oleh karena hidup berasal dari Allah maka hidup harus didasarkan pada nilai-nilai yang di tetapkan oleh Allah ( Nilai-nilai Islam ). Oleh karena kita hidup tapi akan kembali padaNya dan kita hidup harus membangan peradaban maka, peradaban yang kita bangun semasa hidup harus dipertanggung jawabkan di hadapan Nya kelak nanti. Hal ini dapat di ilustrasikan sebagai berikut :

Nilai Islam $\rightarrow$ Peradaban $\rightarrow$ Pertanggung jawaban di Akhirat

Suatu peradaban seharusnya tidak hanya diukur dengan pencarian material jasa. Tapi ia harus di lihat juga dari pencarian 3 tujuan pokok hidup manusia yaitu ibadah pada Allah, Khalifah dibimi dan isti'mar.

Karena ketiga tujuan pokok tersebut, saling terkait dan muaranya adalah beribadah pada Allah. Pemikiran tersebut dapat diilustrasikan sebagai :

${ }^{31}$ Charles, 128. 


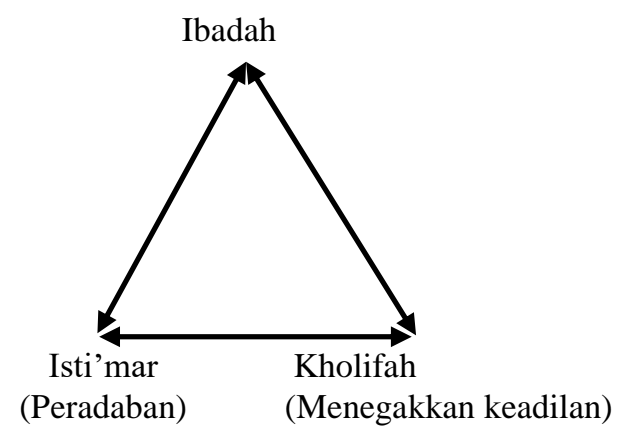

Peradaban dalam islam harus di dasarkan pada nilai - nilai islam yang baku dan harus di kembangkan tapi masih harus dalam bingkai akhlaq, karena harus di pertanggung jawabkan di hadapan Allah di akhirat nanti, pemikiran ini tersebut dapat di ilustrasikan sebagai berikut :

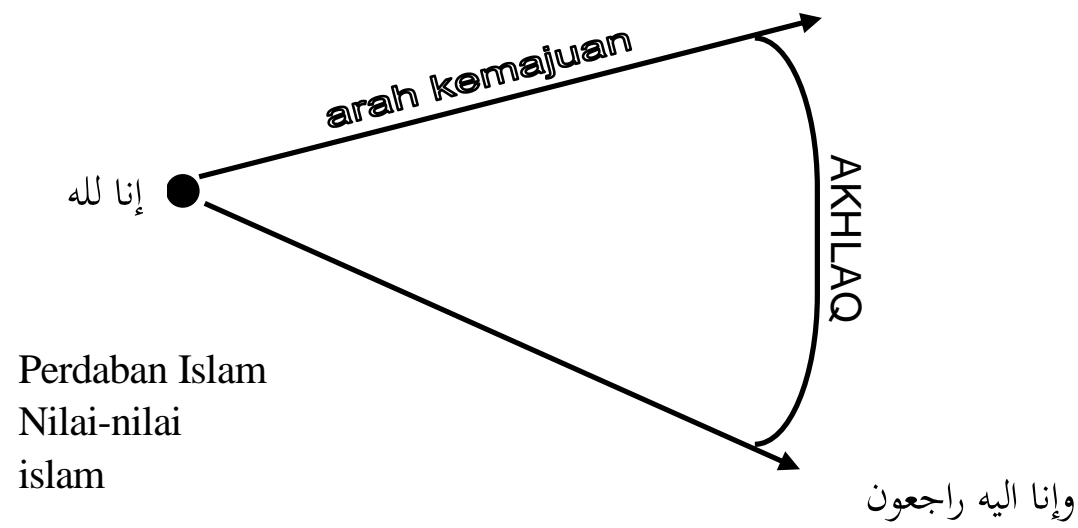

\section{Perbedaan peradaban Islam dan Peradaban Barat adalah :}

Dalam islam, Nilai-nilai melahirkan peradaban. Sedangkan Peradaban Barat berkembang bebas kemusian melahirkan Nilai-nilai sehingga nilai yang di lahirkan bersifat semu dan temporer dan bisa berubah sesuai dengan peadaban yang melahirkan berikutnya sehingga bebas berkembang dan tak tentu tujuan akhirnya. Hal ini dapat di ilustrasikan sebagai berikut :

Peradaban Barat $(\mathrm{I}) \rightarrow$ Nilai $\rightarrow$ Peradaban Barat $(\mathrm{II}) \rightarrow$ Nilai $\rightarrow$ Peradaban Barat $(\mathrm{III}) \rightarrow$ Tak Tentu Tujuan

Dari pemikiran-pemikiran diatas, maka penulis berasumsi bahwa Peradaban Islam merupakan segala uslaha mengimplimentasikan nilai - nilai Islam dalaqm segala aspek kehidupan dengan tetap berada dalam bingkai akhlaq untuk di pertanggung jawabkan kehidupan Allah di Akhirat nanti.

Mengapa Peradaban Islam sulit berkembang ?

Penulis memandang karena Umat Islam sendiri yang mempersempit 
bingkai/ruang gerak Peradaban itu karena keterbatasan pengetahuan mareka tentang. a) Nilai - nilai islam sebagai dasar-dasar bagi peradaban. b) Cara mengimplementasikannya dalam kehidupan ( pengetahuan tentang peradaban ). c) Akhlaq sebagai bingkai peradaban tersebat. Sebagian besar umat islam hanya mengetahui bahwa " Kita hidup untuk mati ". Pandangan mereka ini berimplikasi pada hidupnya yang hanya diisi dengan beribadah Mahdhah pada Allah sedangkan ibadah Ghairu Mahdahnya hanya diwujudkan dengan bersikap baik terhadap keluarga dan tetangga. Padahal ibadah Ghairu Mahdah ini, juga mencakup membangun peradaban. apabila peradaban yang di bangun terus membawa manfaat bagi islam dan kehidupan umat manusia pada umumnya maka menjadi amal Jariyah yang pahalanya terus mengalir tiada henti.

\section{Mengapa terjadi peradaban Islam yang tidak islami ?}

Sebagian umat islam sangat tertarik untuk mengembangkan peradaban tapi mereka mengabaikan nilai-nilai Islam sebagai dasar pijakannya dan mengembangkannya hingga diluar bingkai akhlaq. Sebagai konsekwensi logisnya, terjadi apa yang diperingatkan oleh Allah dalam al-Qur'an :

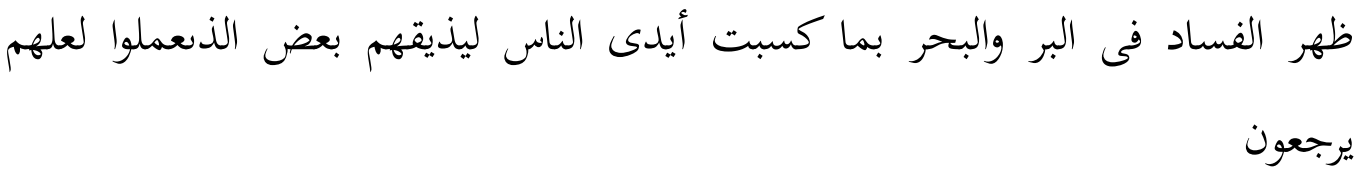

Telah lahirlah bencana di darat dan di laut sebab apa yang diperbuat oleh tangan - tangan manusia. Supaya Allah merasakan pada meraka sebagai apa yang te;ah mereka perbuat mudah-mudahan mereka kemabali ( taubat). (Q.S. Ar Ruum, 41)

Lafadz يرجعون diartikan dengan taubat maksudnya kembali pada nilai-nilai islam dan tetap dalam bingkai akhlaq.

Nilai - nilai dan ajaran - ajaran islam sangat luhur. Hal ini terbukti dengan hadits Nabi الاسلام يعلو ولا يعلى عليه Artinya islam itu Tinggi dan tidak di tinggikan. Akan tetapi keluhuran nilai - nilai dan ajaran Islam sering kali terabaikan dan tidak dapat dirasakan oleh umat islam dan non muslim karena sikap dan tingkah laku umat islam sendiri. Sikapnya tidak mencerminkan keluhuran ajaran islam. Peradabannya tidak mengimplementasikan keluhuran nilai - nilai Islam. Karena itulah Hasan An Nadawy mengatakan : الاسلام محجوب بالمسلمين . Islam itu terhalang oleh orang-orang Islam.

Peradaban Islam akan berkembang jika bisa komonikasi dengan kebudayaan lokal dengan slektif dan tetap berbegang pada nilai-nilai ASWAJA. Jika Islam menelan mentah-mentah terhadap kebudayaan yang berkembang di myasarakat baik budya lokal maupun budaya asing maka Islam akan hilang identitasnya dan ummat Islam akan menjadi lepas dari akar budayanya. Dengan diutusnya Nabi Arab, Muhammad, dan diturunkanya kitab suci, al-Qur'an yang berbahasa Arab, 
menandakan Islam ramah dengan tradisi lokal. Lihatlah, figur Nabi merepresentasikan klan (suku) Arab dan bahasa al-Qur'an adalah cermin bahasa resmi yang berlaku di Arab. Ini adalah bukti orisinil Islam mengadopsi tradisi, sebab Muhammad dan bahasa Arab hakekatnya adalah "anak resmi" dari tradisi lokal Arab, di tanah gersang itulah keduanya dilahirkan.

Bahkan, lepas dari masa awal sejarah Islam Nabi, sebegitu penting peran tradisi lokal, para ulama fikih klasik di masa dinasti Abbasiyyah menjadikannya sebagai pijakan merajut sumber hukum, yang kemudian dikenal dengan terma: al'urf. Sumber hukumpun bertambah, semula 4 jadi 5, yaitu: al-Qur'an, al-Hadis, alijma', al-qiyas dan al-'urf.

Karena Islam tidak memusuhi tradisi malah mengadopsi, maka tidak ada cara lain menghadapinya selain dengan merespon. Di sini, istilah "merespon" merupakan bentuk kerja pro-aktif sebagai bukti bahwa tradisi itu, baik atau buruk, bukan musuh Islam. Merespon adalah cara terbaik untuk menghadapi tradisi baru ketika kita tergiur mempertanyakannya.

Merespon bukan berarti menerima apa adanya, tapi lebih dari itu: merespon adalah sikap yang dibangun dengan memetik sisi kemaslahatan yang ada pada tradisi baru itu. Para ulama fikih klasik menginggatkan urgensitas sebuah "respon" lewat adagium: "al-muhâffadzah 'alâ al-qadîm al-shâlih wa al-akhdz bi al-jadîd alaslah". Intinya, tetap memelihara tradisi klasik yang baik-baik dan dibarengi dengan membuka diri (merespon atau mengadopsi) tradisi baru sejauh itu baik menurut Islam.

Cara proporsional ini pernah diejawantahkan dengan bagus oleh Wali Songo ketika mempercantik bentuk dakwah untuk masyarakat grass root pedesaan. Dakwah para Sunan yang kini diteladani Kyai-kyai NU tuleran nyatanya masih konsekwern mempertimbangkan tradisi sebagai unsur "internal" masyarakat yang tidak bisa dihilangkan begitu saja, oleh karenanya ajaran Islam sebagai unsur "eksternal" yang baru, dipandangnya harus melebur dengan unsur internal untuk mempermudah masyarakat menyerap ajaran Islam yang didakwakan. Gambaran ilustratif para Sunan dan Kyai NU dipotret sebagai usaha merespon tradisi dengan cara mempertahankannya untuk kemaslahatan dakwah Islam.

Seperti misalnya, mengisi tradisi lokal "begadang malam" selama 7 hari setelah wafatnya seseorang dengan senandung dzikir dan lantunan kalimah-kalimah thayyibah, ritual ini sekarang umum disebut "tahlilan" dan sudah mendarah-daging di basis pedesaan.

Huru hara politik pada masa kekhalifahan Islam, lalu berkembang ketika terjadinya perdebatan ilmu kalam dan filsafat dan menjadi sistematis ketika masuk dalam organisasi Nahdlatul Ulama sudah mempunyai seperangkat nilai-nilai, norma-norma dan landasan-landasan yamg bisa dikembangkan untuk kehidupan masa kini, dan itu adalah tugas kita semuanya agar sekiranya aswaja tetap menjadi 
konsteksual.

Persoalan yang muncul hari ini adalajh persoalan perang ideology dan pemikiran, dimana serbuan ideology-ideologi impor begitu kencangnya dan menerobos dalam sendi-sendi kehidupan masyarakat Indonesia.Serbuan pemikiran dan ideology tersebut sama bahayanya dan dapat mengoyak-oyak sendi kehidupan bangsa khususnya penghancuran secara sistematis organisasi Nahdlatul Ulama yang mempunyai basis sosial kuat dan kepemimpinan otoritatif para ulama

\section{Kesimpulan}

1. Kebudayaan dan peradaban sama-sama menunjukkan pada seluruh pandangan hidup manusia, tapi suatu peradaban adalah bentuk yang lebih luas dari kebudayaan.

2. Faktor-faktor yang mempengaruhi perkembangan peradaban meliputi faktor alam, kebiasaan, pelapisan sosial, ideologi, kepercayaan / religi dan Iptek.

3. Sistem nilai dalam Islam harus di terapkan daam membangun peradaban.

4. Memperhatikan peradaban Islam termasuk memakmurkan bumi dan bagian dari tugas Khalifah manusia di bumi, dengan demikian mengandung nilai ibadah kepada Allah.

5. Peradaban Islam dimulai sejak zaman Rasulullah dan mencapai puncak keemasannya pada zaman Daulah Bani Umayyah dan Abbasiyah dan mengalami kemuduran sejak adanya Perang Salib dan mengalami jatuh bangun hingga saat ini.

6. Peradaban Islam di masa depan harus mampu menjadi salah satu pilar utama dalam tatanan peradaban baru yang disebut peradaban post globalisasi atau post kolonialisme.

7. Peradapan Islam akan berkembang dengan baik jika mampu melaksanakan dengan cara yang benar al-mukhafadhatu bil qadimish shalih wal akhdu bil jadidil ashlah, Mempelihahara dan mempertahan kebudayaan yang lama yang masih relepan dan mengambil kebudayaan baru yang lebih baik.

\section{Daftar Pustaka}

Abu Faris Moch. Abd. Qodir, Al Qadhâ'u fi al Islâm. cet 1, Oman: Maktabatul Aqshâ, 1978.

Ahadiyanto, Nuzul. Hubungan Dimensi KepribadianThe Big Five Personality Dengan Tingkat Kesejahteraan Psikologis Narapidana. Jurnal Al-Hikmah, 2020, 18.1: 117-130.

Alwi, Muhammad Muhib. Pemberdayaan Ekonomi Masyarakat Berbasis Masjid di Tengah Pandemi Covid-19. Jurnal Al-Hikmah, 2020, 18.1: 99-116.

Al Ahsani, Nasirudin. Kepemimpinan Perempuan Pada Masyarakat dalam Perspektif Sa īd Ramaḍān Al-Būṭī (Telaah Hadis Misoginis). Jurnal AlHikmah, 2020, 18.1: 57-74. 
Al Qardawy, Yusuf. al Islâm wa al Ilmâniyah Wajhân li Wajhi. Beirut: Muassasah al Risâlah, 1992.

Al Qardawy, Yusuf. Al Islâmu Hadhârat al Ghad. terj. Mustholah Maufur Al Kautsar. Jakarta: Pustaka Al Kautsar, 1996.

Al Qardawy, Yusuf. Al Khasâishu al 'Ammah li al Islam. cet. 2. Beirut: Muassasah Al Risalah, 1983.

Al Qardhawy, Yusuf. Al Imân wa al Hayâh. Beirut : Al Risalah, 1998.

Al Syarqawy, Effat. Filsafat Kebudayaan Islam. cet. 1. Bandung: Pustaka, 1986.

Amal, Khusna. “ Membangun Peradaban Post Globalisme ( Telaah terhadap Pemikiran Hassan Hanafi ) ". al Adâlah. 9 . 2006. 22.

Amstrong, Karen. Islam : A short History. Terj. Ira Puspito Rini. Yokyakarta : Ikon Teralitara, 2002.

An Naim, Abdullah Ahmad. Mohammad Arkoun. dkk. Islamic Law Reform and Human Rights Challonges and Rejoinders, Terj. Farid Wayidi. Yagyakarta : LkiS, 1996.

As-Siba'i, Musthafa Husni. Min Rawâi Hadarâtinâ. Terj. Adbullah Zaky Alkaf. Bandung : Pustaka Setia.

Az Zuhaily, Wahbab. Ushîl al fiqh al Islâmy. Bairut : Darul Fikr, 1986.

Az Zuhaily, Wahbah. Al Qur'an al Karim Bunyatuhu al Tasyrî'iyyatu wa Khasâisuhu al Hadhâriyah. Beirut: Darul Fikr Al Muashir, 1993.

Azizy, Qodry. Melawan Globalisasi Reinterpretasi Ajaran Islam. Yogyakarta : Pustaka Pelajar, 2003.

Chapra, Umer. Islam and The Economic Challenge. Terj. Ikhwan Abidin Basri. Jakarta : Gema Insani Press, 2000.

Dawud, Mochammad. Menerapkan Manajemen Strategi Penyiaran untuk Penyiaran Dakwah. Jurnal Al-Hikmah, 2019, 17.1: 109-140.

Dawud, Mochammad; Choliq, Abdul. Manajemen Strategi Ala NU Tv 9

Menghadapi Televisi Swasta Lokal di Surabaya. Jurnal Al-Hikmah, 2020, 18.1: 75-98.

Elanda, Yelly. Komodifikasi Agama pada Perumahan Syariah di Surabaya. Jurnal Al-Hikmah, 2019, 17.1: 41-62.

Effendhie Machmoed. Sejarah Budaya. Jakarta: Rajawali, 1999.

Fauzi, Ahmad. Problematika Dakwah di Tengah Pandemi Covid 19 Mewabah. Jurnal Al-Hikmah, 2020, 18.1: 27-36.

Hadi, H. Sofyan. Manajemen Strategi Dakwah di Era Kontemporer. Jurnal AlHikmah, 2019, 17.1: 79-90.

Hidayat, Komaruddin. Azyuwardi. Demokrasi, Hak Asasi Manusia dan Masyarakat Madani. Jakarta : ICCE UIN Syarif Hidayatullah, 2006.

Hikam, Mohammed. Islam, Demokratisasi dan Pemberdayaan Civil Society. Jakarta : Erlangga, 2000.

Huntington Samuel P. The Clash Of Civilization and The Remaking Of Word Order. terj. M. Sadat Ismail. cet. 6, Yogyakarta: Qalam, 2003.

Isfironi, Mohammad. Kota Santri, Bumi Shalawat Nariyah dan Bule-Dhika. Jurnal Al-Hikmah, 2019, 17.1: 1-20. 
Jannah, Hasanatul. Pondok Pesantren Sebagai Pusat Otoritas Ulama Madura. Jurnal Al-Hikmah, 2019, 17.1: 91-108.

Jihat, Nur. " Implementasi Undang - undang nomor 38 tahun 1999 tentang Pengelolaan Zakat ", Hukum, 17. Agustus, 2001, 67.

Khalil, Rasyad Hasan. Mafhum Al Musâwah fi al Islâm Dirôsah Muqâranah. Riyadh : Dar al Rasyid li al Nasyr wa al Tauzi', tt.

Kurzman Charles. Liberal Islam : A Sourcebook. Terj. Bahrul Ulum, Heri Junaidi. Jakarta : Paramadina, 2003.

Madjid Nur Kholish. Islam Doktrin dan Peradaban. cet. 4, Jakarta: Paramadina, 1992.

Nandy, Ashish. "Appression and Human Liberation : Tawards A third World Uptopia “, Alternatives, IV ( 1978. 1979 ).

Nasabe, Hisyam. Moslem Educational Institusions. Bairut : Riyadh solh sguare, 1998.

Posman Simanjuntak . Antropologi. Jakarta: Erlangga, 1997.

Quthb Sayyid. At Tashâwwar al Islâm wa Muqawwamâtuhu. terj. Abu Laila. Bandung: Al Ma'arif, 1988

Rahmat, Jamaluddin. " Kepemimpinan Politik dan Cita Keadilan : Perspektif Sejarah Islam. " Al Hikmah, 1993. 61-62.

Rias, Amin. Tauhid Sosial. Bandung : Mizan, 1988.

Saifuddin, A.M. Ada Hari Esok. Jakarta : Amanah putera Nusantara, 1995.

Setiawan, Eko. Makna Nilai Filosofi Wayang Kulit Sebagai Media Dakwah. Jurnal Al-Hikmah, 2020, 18.1: 37-56.

Wahid, Abdur Rahman. Prisma Pemikiran Gus Dus. Yokyakarta : LKIS, 1999.

Yatim Badri. Sejarah Peradaban Islam. Jakarta: Raja Gravindo Persada, 2004.

Wazis, Kun. Perlawanan Ahli Hadis terhadap Gerakan Radikalisme Dalam Konstruksi Media Online. Jurnal Al-Hikmah, 2019, 17.1: 20-40. 